\title{
Serine/Threonine-Protein Kinase ATR
}

National Cancer Institute

\section{Source}

National Cancer Institute. Serine/Threonine-Protein Kinase ATR. NCI Thesaurus. Code C21430

Serine/threonine-protein kinase ATR (2644 aa, 301 kDa) is encoded by the human ATR gene. This protein plays a role in protein phosphorylation, DNA repair and cell cycle progression. 